\title{
Pengajaran Bahasa Inggris Melalui Siaran Radio Komunitas Periode II
}

\author{
Ni Gusti Ayu Roselani
}

Prodi Sastra Inggris, Departemen Bahasa dan Sastra, Fakultas Ilmu Budaya, UGM Pos-el: roselani@ugm.ac.id

Tim Pengabdian kepada Masyarakat:

Ni Gusti Ayu Roselani, Ashika Paramita, Thomas Joko Priyo Sembodo, Tofan Dwi Hardjanto, Syarifah Hanidar, Adi Sutrisno, Rio Rini Diah Moehkardi, Mala Hernawati, Bernadus Hidayat, Heri Widodo, Intan Khoirun Nisa, Monicha Farah, Ni Wayan Putri D., Guntoro Saputra, Mathilda Claressa, Sarah N., Suha Amani, Fikri Sekar Ajeng, Stephanie Melinda

\begin{abstract}
Balai Budaya Minomartani (BBM) is a community center of Indonesian culture and arts, which has attracted a good number of domestic and foreign visitors. It is located in Minomartani village in Sleman, Yogyakarta. It has a community radio station on FM 107.9 Mhz. Although the radio is quite popular among the surrounding residents, it has a very limited program and none of them is for the young generation, especially children. This good potential has drawn the attention of the Community Engagement team of the English Department of the Faculty of Cultural Sciences of Universitas Gadjah Mada to provide some support in the form of English Lessons radio program. As the targets of the program are children in the community surrounding the center, the lessons make use of mostly fables to be the main teaching materials.
\end{abstract}

Keywords: community radio, Minomartani village, English lessons, fables, teaching materials, children

\begin{abstract}
Abstrak
Balai Budaya Minomartani (BBM) merupakan suatu pusat kebudayaan dan seni Indonesia yang dikelola oleh masyarakat di sekitar lokasi yang telah menarik banyak pengunjung, baik dari Indonesia maupun dari luar negeri. BBM terletak di Desa Minomartani, Yogyakarta. Pusat kebudayaan ini juga memiliki sebuah stasiun radio komunitas yang mengudara pada FM 107,9 Mhz. Meski radio ini cukup disukai oleh warga sekitar, program-program yang tersedia masih sedikit dan tidak ada satupun yang ditujukan untuk generasi muda, khususnya anak-anak. Potensi yang sangat baik inilah yang menarik perhatian tim pengabdian kepada masyarakat Prodi Sastra Inggris, Fakultas Ilmu Budaya, Universitas Gadjah Mada untuk berperan serta memberikan bantuan berupa program siaran radio pelajaran bahasa Inggris. Karena target yang disasar adalah anak-anak, sebagian besar bahan pelajaran yang dipakai adalah cerita fabel.
\end{abstract}

Kata Kunci: radio komunitas, desa Minomartani, pelajaran bahasa Inggris, fabel, bahan ajar, anak-anak 


\section{Latar Belakang}

Dewasa ini, keterampilan berbahasa Inggris dapat dikatakan sulit untuk dipisahkan dari hiruk pikuk kehidupan masyarakat dunia. Seluruh sendi kehidupan manusia di belahan dunia mana pun, suka tidak suka, sedikit banyak telah terkena dampak globalisasi sebagai akibat dari perkembangan teknologi komunikasi yang demikian pesat. Hal ini menyiratkan adanya pemikiran bahwa bahasa Inggris bukan sematamata 'milik' dunia akademis. Keterampilan berbahasa Inggris diperlukan oleh siapa pun yang ingin memiliki kontak dengan kehidupan yang oleh sebagian orang disebut modern. Bahasa Inggris boleh jadi telah mendapatkan label sebagai salah satu alat survival bagi orang atau masyarakat tertentu untuk dikenal oleh masyarakat dunia, yang pada gilirannya diharapkan dapat memberikan mereka keuntungan tertentu terkait dengan dunia materialis tempat hidupnya. Dengan kata lain, penguasaan bahasa Inggris yang memadai menjadi salah satu faktor penting untuk dapat membuka jendela menuju kemungkinan-kemungkinan tak terbatas yang menjamin suatu bentuk kehidupan yang diidamkan oleh seseorang.

Sebaliknya, keterbatasan kemampuan berkomunikasi menggunakan bahasa Inggris diyakini akan dapat menghalangi pengembangan potensi dari masyarakat tertentu. Hal inilah juga menjadi isu yang ditanggapi oleh Program Studi Sastra Inggris melalui program pengabdian kepada masyarakat yang diadakan dalam kurun waktu tiga bulan pada semester genap tahun ajaran 2017/2018. Balai Budaya Minomartani (selanjutnya BBM) yang lokasinya menyatu dengan Perumnas Minomartani ini terbukti memiliki potensi untuk dapat dikembangkan, terutama apabila disertai dengan dukungan yang sesuai dan terarah.

Lokasi gedung yang nyaman dan leluasa untuk berkegiatan, fasilitas yang memadai (termasuk di dalamya perangkat gamelan dan studio radio komunitas), dukungan masyarakat lokal yang antusias, dan pengunjung yang berasal dari berbagai tempat telah dipandang sebagai modal yang baik untuk maju.

\section{Balai Budaya Minomartani}

Tujuan keberadaan BBM, sesuai dengan pernyataan yang tertulis pada laman websitenya, adalah 'tempat bertemu dan mempertemukan, warga dan siapa saja yang mau mengembangkan kebudayaan Indonesia yang ber-Bhineka Tunggal Ika'. BBM telah menjadi tempat bertemunya banyak orang yang tertarik untuk melakukan aktivitas seni, baik seni tari, seni pewayangan, seni musik, seni sastra, maupun seni lainnya. Mereka yang datang ke sana ternyata bukan sebatas warga sekitar BBM, melainkan juga peminat kebudayaan Indonesia yang berasal dari luar Desa Minomartani, bahkan ada pula yang berasal dari luar negeri seperti Singapura, Australia, dan Amerika Serikat. Pada titik inilah persinggungan dengan bahasa Inggris terjadi. Pengembangan BBM ini akan dapat mencapai titik yang relatif lebih tinggi seandainya para aktivis pendukungnya memiliki keterampilan berbahasa Inggris yang memadai untuk dapat memperkenalkan BBM kepada masyarakat yang lebih luas di luar Indonesia.

BBM diharapkan dapat bertahan di masa depan apabila memiliki unsur-unsur pendukung yang tepat. Generasi penerus yang tinggal di sekitar BBM adalah aset 
utama pendukung kegiatan BBM yang perlu dibina sebaik-baiknya. Walaupun berbagai penelitian telah membuktikan bahwa keberhasilan seseorang dalam mempelajari bahasa kedua/asing tidaklah selalu terkait dengan usia (Genesee, 1978:146), setidaknya anak-anak yang mulai belajar bahasa asing kemungkinan memiliki waktu yang lebih panjang dalam usahanya mempelajari suatu bahasa secara berkesinambungan apabila dibandingkan dengan waktu yang dimiliki oleh orang dewasa. Oleh karena itu, anakanak yang tinggal di sekitar BBM merupakan segmen dalam masyarakat yang sangat potensial untuk dapat memperoleh dukungan, khususnya dari tim pengabdian kepada masyarakat Prodi Sastra Inggris, Fakultas Ilmu Budaya, Universitas Gadjah Mada, dalam mempelajari bahasa Inggris.

Tim pengabdian kepada masyarakat Prodi Sastra Inggris merencanakan pendampingan berkelanjutan terhadap generasi muda masyarakat Minomartani yang tinggal di sekitar BBM tersebut.

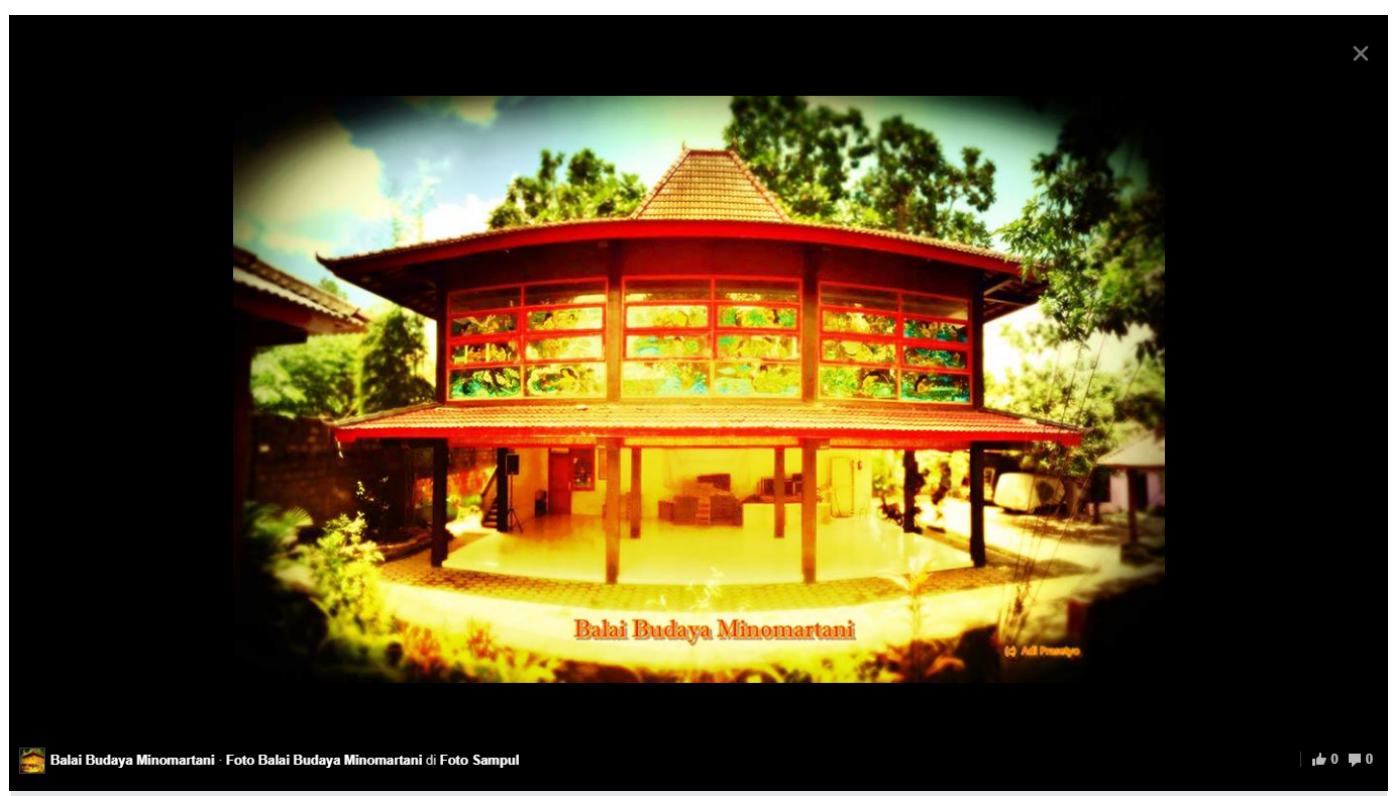

Gambar 1. Balai Budaya Minomartani

\section{Radio Komunitas BBM}

BBM, selain memiliki sarana untuk mementaskan suatu pertunjukan wayang, tari, gamelan dan sebagainya, juga memiliki sebuah radio komunitas yang tampaknya belum dikembangkan secara penuh, dalam arti masih banyak waktu siaran yang belum terisi. Radio ini menguadara pada frekuensi $107,9 \mathrm{MHz}$. Hal ini dianggap sebagai peluang oleh tim pengabdian kepada masyarakat Prodi Sastra Inggris untuk dapat dimanfaatkan dalam memberikan dukungan pengembangan keterampilan berbahasa Inggris bagi anak-anak di sekitar BBM.

Sementara ini, acara-acara siaran radio yang dipancarkan melalui radio komunitas BBM tersebut sangat bergantung pada penduduk desa sekitar lokasi radio tanpa banyak melibatkan masyarakat di luar daerah lokasi radio. Hal ini menyebabkan terbatasnya acara yang dapat disiarkan. Oleh karena mereka yang aktif tersebut adalah penduduk 
yang memiliki pekerjaan tetap di luar aktivitas radio komunitas, maka sangat dapat dimaklumi apabila waktu siaran terpaksa harus menyesuaikan waktu luang yang dapat disisihkan oleh pengelolanya.

Kegiatan yang telah dijalankan oleh tim pengabdian kepada masyarakat Prodi Sastra Inggris telah sedikit banyak membantu terjaminnya acara yang dapat dipancarkan melalui radio tersebut, setidaknya untuk beberapa waktu. Tim pengabdian kepada masyarakat Prodi Sastra Inggris telah berhasil memproduksi serangkaian acara yang memiliki kandungan materi yang bersifat mendidik dan menyenangkan, yang khusus ditujukan bagi pendengar anak-anak dan remaja.

Program pengabdian kepada masyarakat ini tidak hanya bermanfaat bagi masyarakat yang menjadi target, tetapi juga sangat dirasakan manfaatnya khususnya oleh para mahasiswa Prodi Sastra Inggris yang telah dilibatkan di dalamnya. Keikutsertaan mereka dalam kegiatan ini merupakan kesempatan yang sangat berharga untuk menantang diri mereka sendiri dalam melakukan aktivitas yang menuntut beberapa keterampilan sekaligus, khususnya keterampilan membacakan cerita anak.

Di sisi lain, pengalaman ini juga merupakan sesuatu hal yang baru bagi staf pengajar di Prodi Sastra Inggris. Sama seperti para mahasiswa yang terlibat, beberapa staf pengajar juga belum pernah berada dalam situasi rekaman seperti yang telah dikerjakan untuk program ini sehingga pengalaman ini menjadi suatu pengalaman yang sangat berharga apabila dilihat dari beberapa sudut. Mendengarkan suara diri sendiri melalui suatu rekaman adalah hal yang terkadang dapat menyebabkan rasa malu yang sebenarnya sangatlah tidak perlu. Akan tetapi, hal tersebut dirasakan sebagai suatu hal yang sangat manusiawi, yang seringkali tidak terhindarkan.

Mempersiapkan diri untuk merancang sebuah program, yang berdurasi 'hanya' sekitar setengah jam setiap kali mengudara, bukanlah suatu kegiatan yang dapat dilakukan setiap orang tanpa pengetahuan dan keterampilan khusus. Terlebih lagi, proses rekaman haruslah dilakukan di studio yang merupakan situasi yang tidak biasa dialami oleh tim pengabdian kepada masyarakat Prodi Sastra Inggris. Pengenalan situasi studio rekaman, pengenalan penggunaan mikrofon secara benar, pengulangan-pengulangan rekaman yang harus dilakukan apabila terjadi kesalahan-kesalahan, pentingnya perhatian pada detil-detil skrip yang harus dibaca, cara pengucapan yang baik dan benar, serta tinggi rendahnya suara yang harus diatur sedemikian rupa adalah beberapa hal yang akan memberikan manfaat bagi tim di kemudian hari. Para anggota tim pengabdian kepada masyarakat telah 'dipaksa' untuk

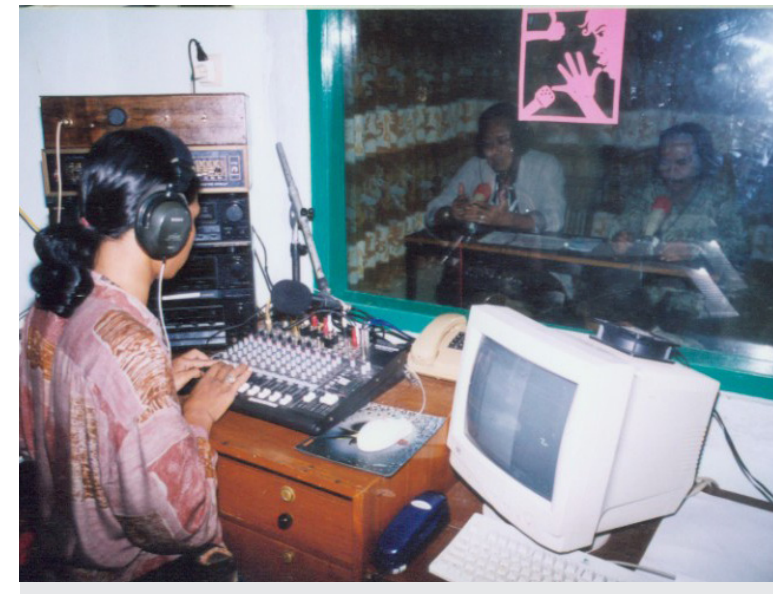

Gambar 2. Studio Radio Komunitas BBM mengembangkan diri mereka sendiri semaksimal mungkin. 


\section{Metode}

Berbagai cara dan sarana dapat dipakai seseorang untuk mempelajari suatu bahasa asing. Secara formal, seseorang dapat mendaftar di suatu institusi yang memang disiapkan untuk menyediakan kelas-kelas sebagai sarana bertemunya murid dan guru. Cara yang lain adalah belajar secara mandiri untuk mendapatkan paparan-paparan bahasa yang akan atau tengah dipelajarinya. Sebagian orang dewasa mungkin sudah lupa akan kekuatan dongeng yang pernah didengarnya pada waktu mereka masih anak-anak. Walaupun lebih tentang cerita pada umumnya, Okri (1996) menunjukkan bagaimana sebuah cerita memengaruhi perkembangan seseorang. Berikut ini adalah kutipannya.

It is easy to forget how mysterious and mighty stories are. They do their work in silence, invisibly. They work with all the internal materials of your mind and self. They become part of you while changing you. Beware the stories you read or tell; subtly, at night, beneath the waters of consciousness, they are altering your world (Okri, 1996:37).

Sangatlah mudah untuk melupakan bagaimana misterius dan perkasanya cerita-cerita itu. Cerita-cerita itu bekerja secara diam-diam dalam kebisuan tanpa dilihat siapa pun. Cerita-cerita itu bekerja bersama semua yang terkandung dalam pikiranmu dan dirimu. Cerita-cerita itu menjadi bagian darimu sembari mengubahmu. Waspadalah terhadap cerita-cerita yang kau baca atau yang kau bacakan; secara lembut, di malam hari, di bawah air kesadaran, cerita-cerita itu akan mengubah duniamu (Okri, 1996:37).

Dongeng selain dapat digunakan sebagai suatu sarana bagi seorang anak untuk mengembangkan dirinya, dapat juga digunakan sebagai sarana untuk mempelajari cara mengatasi suatu masalah yang sedang dialaminya ataupun yang akan dialaminya di kemudian hari. Oleh karena itu, mendongeng dapat menjadi alternatif yang baik untuk sarana belajar, menyenangkan untuk dilakukan, dan juga memiliki manfaat yang nyata.

Dengan memanfaatkan sarana radio komunitas BBM yang telah ada, ide untuk memberikan pelajaran bahasa Inggris kepada anak-anak yang berada dalam jangkauan siaran radio komunitas BBM ini bisa direalisasikan dalam bentuk siaran radio berisi pembacaan cerita anak berbahasa Inggris yang disertai pelajaran sederhana terkait topik cerita yang dibacakan.

\section{Tahap-tahap Perencanaan}

\section{Tim dan Tugas-tugasnya}

Tim inti pengabdian kepada masyarakat Prodi Sastra Inggris terdiri atas:

1. Dosen Prodi Sastra Inggris

2. Delapan mahasiswa

Mahasiswa-mahasiswa yang diminta untuk ikut aktif dalam program ini berasal dari berbagai angkatan. Mahasiswa termuda adalah yang berasal dari angkatan tahun akademik 2017/2018, sedangkan mahasiswa paling senior berasal dari angkatan 2015. Mereka dipilih berdasarkan rekomendasi dari dosen pengampu mata kuliah Berbicara dan juga rekomendasi dari teman-teman mahasiswa itu sendiri. Setelah 
mereka menyatakan kesediaannya, mereka kemudian mulai diikutsertakan dalam pertemuan-pertemuan yang ada.

3. Dua orang pembantu pelaksana.

Tim ini dibagi menjadi dua divisi pokok, yaitu divisi pembaca cerita dan divisi editor rekaman. Sebelum melakukan tugas masing-masing divisi, semua anggota tim juga berunding tentang nama program yang hendak disiarkan. Berdasarkan hasil perundingan tersebut, nama program yang digunakan adalah Story Time.

\section{Tugas pembaca cerita}

Pencerita memiliki beberapa kewajiban sebagai berikut.

1. Memilih cerita yang hendak dibacakan.

Tim inti pengabdian kepada masyarakat telah menyediakan buku-buku cerita anak yang dapat dipilih untuk dimanfaatkan sebagai sumber cerita untuk dibaca. Akan tetapi, pencerita bebas untuk menentukan cerita dari sumber-sumber lain yang dapat dijangkaunya. Cerita yang beragam dan tersedia sangat memudahkan para pencerita dalam melakukan tugasnya.

Cerita-cerita yang menjadi pilihan adalah cerita fabel yang diharapkan akan disukai oleh anak-anak pendengar radio komunitas BBM Minomartani. Tingkat kesulitan bahasa dari cerita-cerita yang dipilih berbeda-beda sehingga sangat penting untuk melakukan penyesuaian-penyesuaian agar mudah dipahami oleh anak-anak. Beberapa penyederhanaan kalimat-kalimat kompleks dilakukan untuk tujuan tersebut. Selain itu, juga dilakukan pengubahan nama yang tidak biasa menjadi nama Indonesia yang lebih mudah dimengerti, seperti 'Sethni' menjadi 'Rani'. Warna 'indigo' diganti dengan 'purple' karena warna indigo kemungkinan besar sulit untuk dibayangkan oleh anak-anak jika dibandingkan dengan warna ungu.

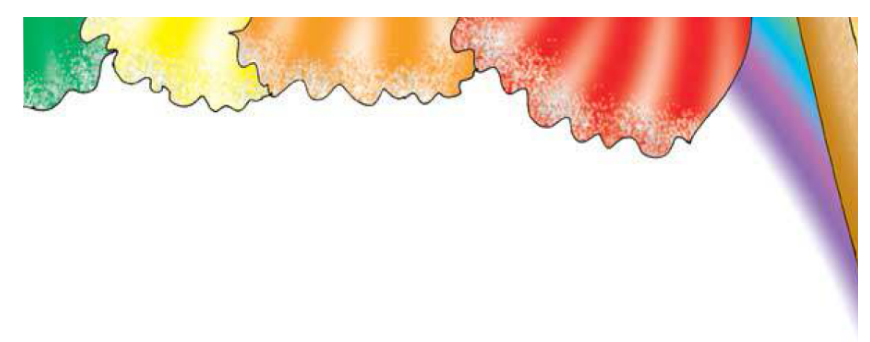

\footnotetext{
"I'm the prettiest. So don't come close to me."

The violet dress pushed the indigo dress away.

"No, it's me, who's the prettiest."

The blue dress pushed all the others away.

The quarrel started again, in the garden.

They pushed, kicked, nudged and pinched eachother

Everyone wanted to be the prettiest.
}

Gambar 3. Contoh Halaman Who is the Prettiest 
Adapun judul cerita-cerita yang dipilih adalah:

- Earthshaker

- June Peters You Will Save the World One Day

- The Two Silly Cats

- Water and Soil

- A Zebra Called Dotty

- A Dancer Tale: Story about Phills Spira

- The Sun Who Lost His Way

- Who is the Prettiest

- Biju Spins some Magic

- Cookie Rookie

- The Tortoise and the Hare

- A Cloud of Trash

Cerita-cerita yang telah dipilih tersebut tidaklah dapat serta merta dibaca. Proses editing dengan maksud menyesuaikan segala sesuatunya dengan target pendengar dilakukan sejalan dengan penulisan naskah rekaman.

2. Memilih sasaran pembacaan cerita.

Pembaca cerita perlu mencermati cerita pilihan masing-masing agar dapat menentukan target khusus untuk acara siaran mereka. Sebuah cerita yang sederhana seperti Who is the Prettiest misalnya, akan lebih sesuai jika diperuntukkan bagi pendengar usia sekolah taman kanak-kanak atau sekolah dasar kelas satu dan dua. Kosa kata yang dipakai dalam cerita ini juga sangat terbatas dan diulang-ulang sehingga kurang sesuai untuk mereka yang sudah lebih tua. Cerita lainnya, seperti The Tortoise and the Hare mengandung kosa kata yang cenderung lebih banyak dan struktur bahasa yang jauh lebih rumit daripada yang terdapat dalam cerita Who is the Prettiest sehingga akan lebih pantas apabila diperuntukkan bagi pendengar anak-anak yang lebih tua.

Tingkat-tingkat kesulitan dari cerita-cerita pilihan telah membuat para pembaca cerita untuk menentukan tingkatan anak-anak calon pendengar dalam tingkat-tingkat sebagai berikut.

- anak usia TK

- anak usia SD kelas $1-3$

- anak usia SD kelas 4-6

- anak usia SMP.

Pemilihan cerita yang sesuai dengan target akan sangat memengaruhi kualitas naskah yang ditulis, yang pada gilirannya juga akan memengaruhi kualitas siaran yang dihasilkan.

3. Menentukan isi dan menulis naskah cerita.

Penulisan naskah cerita untuk siaran berdurasi tigapuluh menit merupakan suatu hal yang baru untuk semua pencerita. Hal itu menjadi keuntungan tersendiri karena pada semester sebelumnya, dalam periode I pengabdian kepada masyarakat Prodi Sastra Inggris, anggota tim telah memperoleh pengetahuan seputar keterampilan 
penulisan naskah siaran sehingga mempermudah pengerjaan tugas tersebut. Keterampilan menulis naskah ini ditularkan kepada mereka, khususnya mahasiswa, yang belum mengetahuinya.

Karena pemilihan cerita dilakukan dengan sangat berhati-hati, penulisan naskah menjadi suatu hal yang menarik dan tidaklah terlalu sukar untuk dilaksanakan. Beberapa hal yang harus diperhatikan adalah memilih penyebutan untuk diri sendiri (pembaca cerita) ataupun untuk pendengar. Hampir semua pencerita lebih suka memilih sapaan "Kak" untuk menyebut dirinya, seperti Kak Rose dan Kak Mala. Hanya ada seorang pencerita yang memilih sapaan "Bu", yaitu Bu Hani dan Bunda, yaitu Bunda Rio.

Setelah menentukan panggilan untuk diri sendiri, keputusan untuk memilih nama sapaan bagi pendengar juga menjadi isu yang cukup menarik. Pada akhirnya, banyak pencerita yang memilih 'sobat' atau 'sahabat cilik radio BBM' daripada menggunakan istilah 'pendengar'.

Setelah permasalahan terkait nama sapaan selesai, pencerita mulai mencermati cerita pilihan masing-masing dengan lebih baik lagi untuk menentukan poin-poin kebahasaan yang layak untuk ditampilkan dalam siaran, yang sesuai dengan target pendengar yang telah ditentukan sebelumnya. Pada tataran ini, poin kebahasaan yang dipilih lebih mengarah kepada kosakata-kosakata yang dianggap cukup sering muncul di dalam cerita sehingga apabila tidak mengetahui artinya, seorang pedengar akan merasa kesulitan memahami cerita yang didengarnya. Cerita Who is the Prettiest, misalnya, mengandung kosakata warna yang bermacam-macam yang muncul dalam setiap halaman sehingga sangat penting bagi pencerita untuk mengenalkan kosakata warna tersebut kepada pendengar.

Hal yang terkait erat dengan kosakata adalah pengucapan kata-kata yang dipilih untuk diperkenalkan artinya. Pengucapan dianggap sangat penting untuk diajarkan karena tanpa mengetahui bagaimana mengucapkan sebuah kata dengan benar, kata tersebut tidak akan dapat dipahami oleh orang yang tidak mengetahui cara mengucapkannya secara benar. Penekanan yang berbeda diterapkan pada masing-masing cerita sehingga terdapat banyak ragam poin kebahasaan yang ditampilkan.

Setelah tahap seleksi poin-poin kebahasaan, hal berikutnya yang harus dipikirkan adalah memformulasikan poin-poin pelajaran keteladanan yang terkandung dalam cerita-cerita tersebut. Sebagai contoh, cerita dalam dongeng berjudul Who is the Prettiest menunjukkkan kepada pembaca/pendengarnya untuk tidak saling iri dengki. Cerita ini mendorong anak-anak untuk saling membantu sehingga tercapai persahabatan yang harmonis di antara mereka. Diharapkan nantinya pelajaran-pelajaran berharga semacam itu akan tertanam dalam diri anakanak pendengar sehingga akan membantu mereka bertumbuh menjadi orang yang peduli terhadap sesama. Contoh yang lain adalah keteladanan yang ditunjukkan dalam cerita The Tortoise and the Hare. Cerita ini memberikan gambaran perilaku seseorang yang merendahkan orang lain yang menyebabkan dirinya merugi.

Pada intinya, cerita-cerita yang dipilih adalah cerita yang mengandung pesan moral yang baik, yang memang diperlukan untuk memberikan inspirasi dan bimbingan bagi anak-anak agar mereka dapat meneladani cerita-cerita tersebut. 
Setelah mendengar cerita tersebut, para pendengar cilik itu diharapkan untuk dapat merealisasikannya dalam tingkah laku mereka sehari-hari sehingga menjadi anak yang memiliki moral dan perilaku yang baik.

Naskah ditulis dalam dua bahasa, yaitu bahasa Indonesia dan bahasa Inggris. Bahasa Indonesia digunakan sebagai bahasa pengantar untuk membuka dan mengantarkan pembacaan cerita serta kemudian menutupnya. Bahasa Inggris digunakan saat pembacaan cerita-cerita yang dipilih. Sebagai catatan, cerita-cerita tersebut tertulis dalam bahasa Inggris.

Yang tidak kalah penting dalam penulisan naskah siaran ini adalah pemilihan lagu yang disertakan di dalamnya. Lagu yang terkait dengan tema cerita dapat disediakan sendiri oleh pembaca cerita atau juga meminta bantuan dari editor hasil rekaman. Sebagai contoh, cerita Who is the Prettiest yang banyak menyebutkan warna diisi dengan lagu bertema warna. Demikian juga dengan cerita-cerita yang memiliki tema berbeda akan sedapat mungkin dicarikan lagu yang memiliki isi lirik yang sesuai. Pemilihan lagu ini bukan suatu tugas yang mudah, melainkan memerlukan keterampilan dan pengalaman yang dimiliki oleh anggota tim. Tugas ini dapat dilaksanakan sesuai target yang diharapkan.

\section{Tugas editor}

Di pihak lain, divisi editor bertugas untuk melakukan pengeditan terhadap hasil rekaman. Hasil rekaman yang diperoleh dari studio rekaman masih berupa rekaman yang apa-adanya, yakni tanpa tambahan lagu ilustrasi ataupun penyesuaian jeda-jeda waktu yang terkadang belum tertata secara sempurna. Tugas mengedit tersebut dibebankan kepada divisi editor dengan

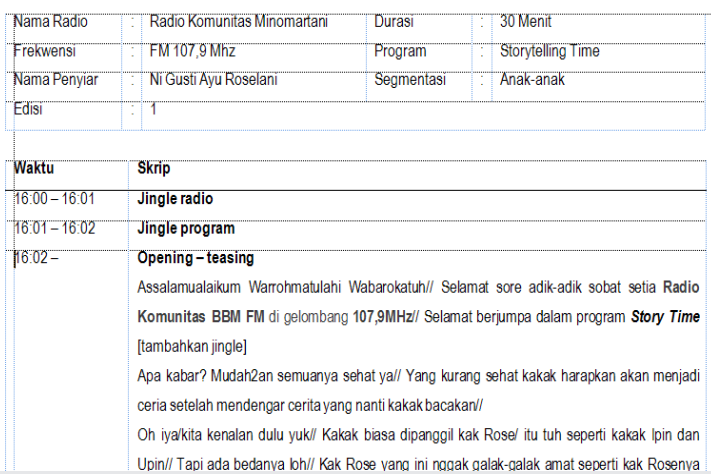

Gambar 4. Contoh Halaman Naskah Rekaman juga memperhatikan unsurunsur berikut.

1. Menambahkan jingle radio komunitas BBM.

Jingle atau lagu tema radio BBM telah tersedia sehingga tim editor tidak perlu mencarinya. Jingle ini akan diperdengarkan sebelum dan setelah dimulainya acara siaran radio.

2. Menambahkan jingle program Story Time.

Lagu tema untuk program Story Time ini dipilih oleh tim editor dengan mengunduhnya dari laman web yang legal tanpa bayar. Jingle program ini akan diperdengarkan setelah jingle radio BBM dan di sela-sela pembacaan cerita. Bersama dengan jingle radio, jingle program diperuntukkan bagi semua cerita yang dibacakan oleh tim pencerita. 
3. Menyelaraskan hasil rekaman sehingga layak untuk disiarkan.

Penyelarasan ini dilakukan oleh tim pengabdian kepada masyarakat Prodi Sastra Inggris karena beberapa anggota tim memiliki kemampuan dan bersedia untuk melakukannya.

Karena semua anggota tim bukan pelaku profesional pembaca cerita anak, penjajagan tentang dasar-dasar pembacaan cerita anak dan dasardasar melakukan perekaman suara perlu dipelajari. Oleh karena itu, tim memutuskan untuk mengundang seseorang atau pihak yang memiliki keahlian terkait dengan hal-hal tersebut.

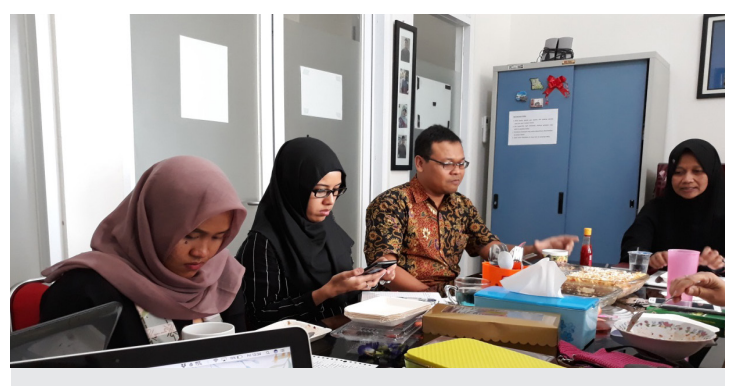

Gambar 5. Pertemuan Tim Pengabdian

\section{Lokakarya Pembacaan Cerita}

Tahap berikutnya adalah workshop cara membaca cerita dan tata cara rekaman suara untuk menambah keterampilan para pembaca cerita supaya memperoleh hasil rekaman yang bermutu tinggi. Tim pengabdian kepada masyarakat Prodi Sastra Inggris menghadirkan Dr. Eddy Pursubaryanto sebagai narasumber sehingga mendapatkan tambahan pengetahuan dan keterampilan seperti di bawah ini.

1. Cara menyesuaikan cerita dengan target pendengar

Tahap ini sedikit banyak telah dipaparkan di bagian tugas pencerita di atas. Penekanan yang perlu diperhatikan dalam tahap ini adalah membaca dengan cermat cerita yang dipilih untuk kemudian menandai bagian-bagian yang perlu dikemukakan dalam rekaman dengan tujuan membantu para pendengar (anak-anak) memahami cerita yang dibacakan. Hal ini perlu dilakukan mengingat kemampuan anak-anak yang menjadi pendengar radio BBM tersebut dapat dipastikan sangat beragam.

2. Cara menyesuaikan tingkat kecepatan bercerita

Menyesuaikan diri untuk berbicara dengan kecepatan yang tepat bukanlah sesuatu yang mudah untuk dilakukan. Diperlukan latihan terus menerus sehingga kebiasaan sehari-hari untuk berbicara dengan tempo cepat atau sebaliknya dapat diubah sesuai dengan kebutuhan. Berbicara dengan jelas dan tempo yang sedang akan membantu pendengar memahami cerita yang dibacakan dengan mudah. Sebaliknya, tidak semua pendengar akan mudah memahami seseorang yang berbicara terlalu cepat.

3. Cara menyelaraskan nada suara saat bercerita

Seseorang secara alami memang memiliki nada suara tertentu yang perlu diatur sedemikian rupa supaya sesuai dengan karakter yang dibacakannya. Hal itu sudah dicontohkan dalam pertunjukan wayang kulit yang mengharuskan seorang dalang untuk dapat menyesuaikan nada suaranya dengan karakter-karakter tertentu yang dikehendakinya. 
4. Cara bercerita agar menarik dan 'hidup'

Cara membaca cerita yang datar dan tanpa semangat akan 'mengusir' pendengar. Sebaliknya, pembacaan cerita yang mengikutsertakan ekspresi yang tepat dan sesuai dengan karakter yang dibacakannya akan membuat pendengarnya tertarik dan tekun mendengarkan sampai tuntas.

5. Cara menghadapi pengeras suara (microphone)

Walaupun terdengar sangat remeh, menyesuaikan diri berbicara di hadapan sebuah pengeras suara (microphone) yang sangat peka terhadap bunyi sangat lembut memerlukan usaha yang cukup keras sehingga rekaman yang dihasilkan jernih dan baik.

6. Cara mempersiapkan naskah rekaman

Seperti yang telah dipaparkan sebelumnya, tim pengabdian kepada masyarakat Prodi Sastra Inggris periode sebelumnya telah mendapatkan pengetahuan dan pelatihan keterampilan menulis naskah siaran radio. Oleh karena itu, lokakarya yang diadakan kali ini lebih bersifat penyegaran. Fasilitator menjabarkan kembali yang dimaksud dengan naskah rekaman dan hal-hal yang perlu dituliskan. Kegiatan ini sangat menarik minat mahasiswa yang belum pernah mengetahuinya dan sangat membantu proses perekaman suara untuk pembacaan cerita setelahnya.

7. Cara pemilihan lagu yang tepat

Fasilitator dalam lokakarya juga memberikan beberapa saran terkait pemilihan lagu-lagu yang sesuai untuk kegiatan ini. Beberapa poin penting yang diperoleh adalah disarankan untuk memilih lagu yang riang karena pendengarnya adalah anak-anak dan mengunduhnya dari laman website dengan mempertimbangkan aspek hukum.

Tim PKM benar-benar memanfaatkan kesempatan dalam workshop ini untuk berlatih membaca cerita sehingga timbul rasa percaya diri untuk tampil dalam rekaman.

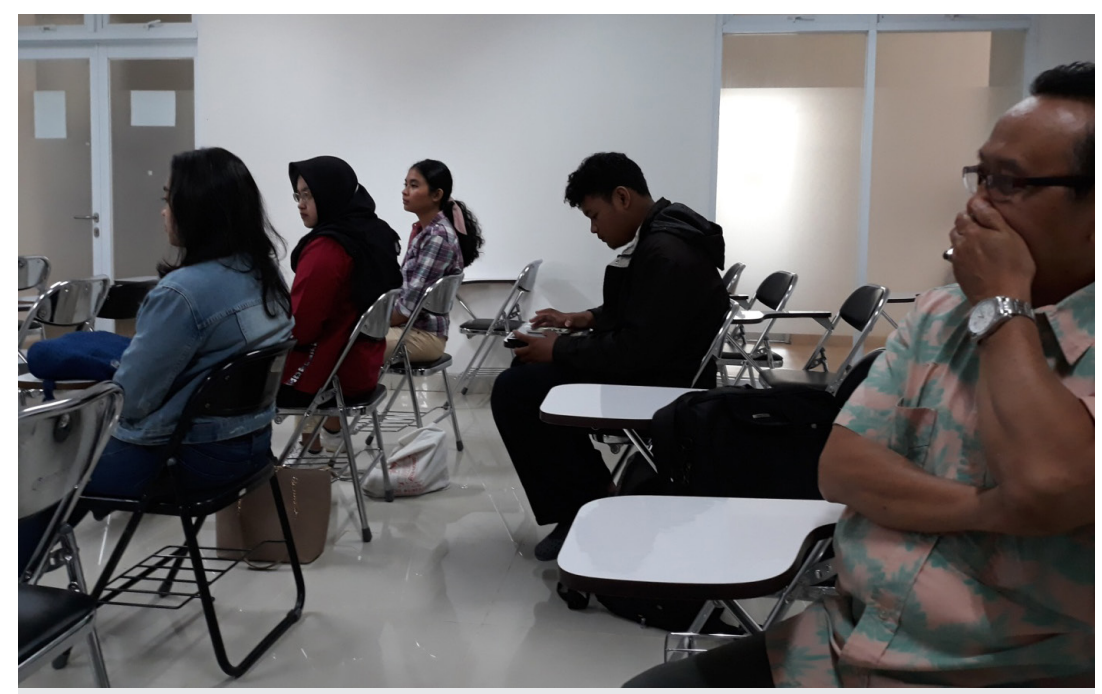

Gambar 6. Workshop Pembacaan Cerita 


\section{Proses Perekaman}

Studio rekaman yang dipilih untuk kesempatan kali ini telah terbukti memiliki pengalaman yang cukup baik dalam membantu perekaman percakapan bahasa Inggris. Letaknya tidak terlalu jauh dari kampus Universitas Gadjah Mada sehingga memudahkan tim pengabdian kepada masyarakat Prodi Sastra Inggris untuk bergiliran melakukan perekaman suara.

Pada kenyataannya, target hasil perekaman setengah jam untuk setiap pembaca cerita memerlukan waktu setidaknya satu jam dalam pelaksanaannya. Hal ini disebabkan oleh persiapan-persiapan yang harus dilakukan terlebih dahulu, baik oleh pembaca cerita maupun oleh operator perekaman. Selain itu, pembaca cerita juga perlu menyesuaikan diri dengan situasi di dalam studio

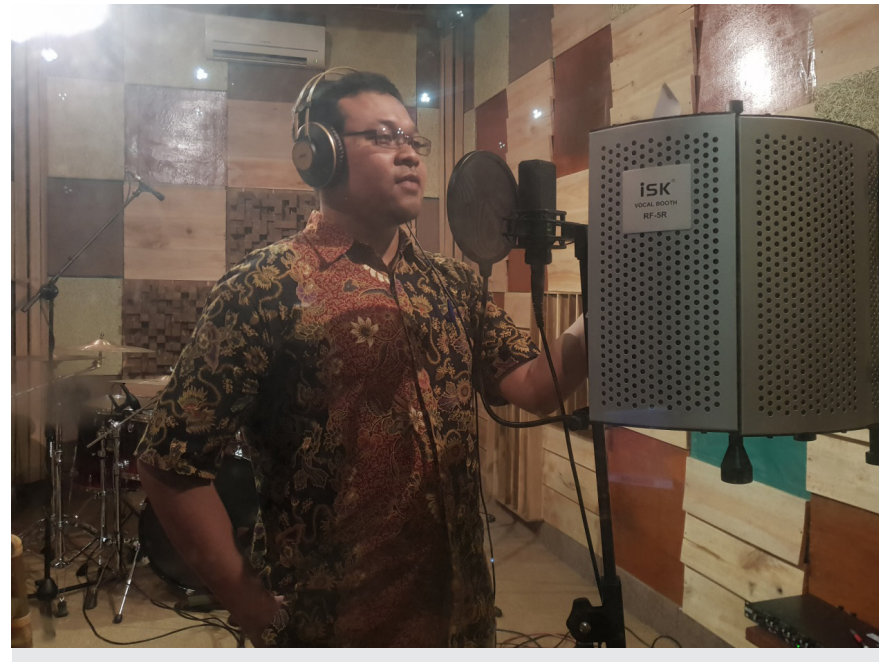

Gambar 7. Proses Perekaman Pembacaan Cerita rekaman. Sebagai contoh, seorang pembaca cerita harus dapat menyesuaikan jarak dengan pengeras suara agar dapat dihasilkan suara yang jelas dan harus selalu mengingat posisinya berdiri. Perubahan yang terjadi sedikit saja dapat memengaruhi kualitas suara yang dihasilkan. Selain itu, seorang pembaca cerita juga harus mengontrol dirinya agar tidak menghasilkan suarasuara yang tidak dimasudkan masuk di dalam rekaman.

Satu hal yang sering menjadi masalah adalah kesalahan membaca yang mengakibatkan proses rekaman harus dihentikan dan kemudian diulang. Kesalahan membaca ini menjadi kesalahan yang jamak dilakukan oleh seorang pembaca cerita. Tidak ada seorang pembaca ceritapun yang tidak pernah mengulang suatu kalimat tertentu.

\section{Proses Penyiaran Hasil Rekaman}

Penyiaran hasil rekaman yang telah dilakukan oleh tim pencerita pengabdian kepada masyarakat Prodi Sastra Inggris ini sangat tergantung dari penjadwalan yang dilakukan oleh pihak radio komunitas BBM. Tim pengabdian kepada masyarakat Prodi Sastra Inggris harus melakukan koordinasi untuk dapat mengetahui jadwal siaran. Selain itu, tim juga perlu meminta masukan kepada pihak radio BBM terkait tanggapan masyarakat pendengar radio BBM nantinya. Hal ini diperlukan untuk menentukan langkah-langkah yang hendak dilakukan pada masa yang akan datang, seperti perlunya merencanakan program lanjutan dengan variasi kegiatan yang berbeda atau kegiatan yang serupa, dan lain-lain. 


\section{Referensi}

Genesee, F. 1978. Is there an optimal age for starting second language instruction? In McGill Journal of Education/Revue Des Sciences de l'éducation de McGill, 13(2002). Okri, B. 1996. Birds of Heaven. London: Phoenix. 